\title{
Analysis of Interest and Scientific Literacy Skills of Senior High School in Learning Physics
}

\author{
Dian Fadila, S. Suliyanah \& Utama Alan Deta* \\ Physics Education Program, Faculty of Mathematics and Natural Science, Universitas \\ Negeri Surabaya, Indonesia
}

*Corresponding Author Email: utamadeta@unesa.ac.id

\section{Article History}

Received: November 2020

Accepted: December 2020

Published: December 2020

Key Words

Scientific literacy;

scientific phenomenon

How to cite this article?

\begin{abstract}
Scientific literacy is the ability to use scientific knowledge. This study aimed to describe the understanding of high school students regarding scientific literacy and to describe the influence of high school students' interest in learning on science literacy learning outcomes. This study involved 201 high school students in Surabaya, Sidoarjo and Gresik. This study uses a mixedmethod, namely, by using a quantitative approach and a qualitative approach. Quantitative analysis was performed using regression and correlation tests. Qualitative research was obtained from the results of questionnaires and student interviews. The responses from students were categorized into four levels, namely not answering, not quite right, right, and very precise. The regression test results obtained a significance value (Sig.) Of $0.095>0.05$, which means that there is no influence of students 'interest in learning on the results of students' scientific literacy skills while the correlation test obtained a significance value of $0.095>0.05$, which means that $\mathrm{HO}$ is accepted. and $\mathrm{H} 1$ is rejected. So that there is no significant correlation between the variables of student interest and the results of scientific literacy skills, this research can be concluded that the science literacy skills of high school students are still low and there is no effect of high school students' interest in learning on science literacy learning outcomes. It can be recommended that students can improve their understanding of scientific literacy by getting used to reading scientific literacy before learning begins so that students' interest in reading scientific phenomena increases.
\end{abstract}

Fadila, D., Suliyanah, S., \& Deta, U., A. (2020). Analysis of Interest and Scientific Literacy Skills of Senior High School in Learning Physics. Lensa: Jurnal Kependidikan Fisika, 8(2), 39-47. doi:https://doi.org/10.33394/j$\underline{\text { kff.v8i2.3195 }}$

\section{INTRODUCTION}

The challenges of the 21st century are that there is an inseparable relationship between natural science (science) and technology. Science and technology have a massive role in improving the welfare of humanity (Rohman et al., 2017; Gurses et al., 2015). The 21 st century is the age of knowledge, the century where information is famous, and technology develops. In line with the goals of 21st-century education, 21st-century learning emphasizes the ability of students to find out from various sources, formulate problems, think analytically and collaborate and collaborate on issues (Litbang Kemendikbud, 2007). Education currently leads to a process of activities that can shape students to face the globalization era, environmental problems, advances in information technology, the convergence of knowledge-based science and technology, the awakening of creative and cultural industries, shifting of world economic power, and the influence and impact of science-based technology (Asyhari \& Hartati, 2015; Khaeroningtyas et al., 2016; Azizah et al., 2015). In this regard, mastery of literacy in reading, mathematics, and science is something that must take into account. That is, learning activities should orient 
towards the learning process and implementation of knowledge (Khaeroningtyas et al., 2016; Ardianto \& Rubini, 2016).

Science literacy is a person's ability to understand science, communicate science, and apply scientific knowledge to solve problems so that they have a high attitude and sensitivity to themselves and their environment in making decisions based on scientific considerations (Ardiansyah et al., 2016; OECD, 2015). Thus, scientific literacy is needed by every individual in his life. Learning strategies must determine to be well developed to train scientific literacy, including explaining natural phenomena, constructing and evaluating experiments, and interpreting data obtained from scientific evidence (OECD, 2015; Abdullah, 2014; Septiani et al., 2019). The results of the Trends International Mathematics and Science Study (TIMSS) and the Program for International Student Assessment (PISA) show that the thinking skills, scientific and mathematical literacy of Indonesian students are low. The low scientific literacy of students is suspected because the learning process has not met the requirements and demands of the 21st century (Karim et al., 2017; Rahayu, 2014; Demirel \& Belkiz, 2015).

The condition of students in terms of literacy towards literacy, especially science in physics subjects, is still low (Sukowati, 2017). Where the average score of students' scientific literacy skills as a whole is included in the short criteria (Amalia, 2015), the students' scientific literacy completeness in the city of Solok is classified as "very low" (Angraini, 2014) and the level of students' scientific literacy completeness. Meanwhile, the average scientific literacy ability in the aspects of knowledge and competence is generally in the "good" achievement category (Sukowati, 2017; Wulandari \& Sholihin, 2016). In line with the research (Septian et al., 2019; Asyhari \& Hartati, 2015; Wen et al., 2020) students' scientific literacy explained that scientific phenomena were included in the excellent category based on measurements with the developed test instruments.

Several studies have noted that several things cause students' scientific literacy to below, namely learning material that has never been studied, students are not used to working on questions using discourse (Angraini, 2016), this is supported by research conducted because students are not familiar with the questions scientific literacy (Rohman et al., 2017). So that the science literacy value of students is low, still, it can be seen that from some of these studies, it is not known the effect of students 'interest in learning on the results of students' scientific literacy abilities. There is still little research on the interests and skills of students in high school science literacy, especially in the areas of Surabaya, Sidoarjo and Gresik, so research is needed related to scientific literacy interests and abilities. This study aims to identify students 'interest in learning physics and to identify the influence of high school students' interest on scientific literacy outcomes involving five schools in the Surabaya, Sidoarjo and Gresik areas that have never been done before.

\section{METHOD}

This research was conducted by involving 201 respondents from 11th-grade high school students in the Department of Mathematics and Natural Sciences. Respondents obtained from 5 different schools in the Surabaya, Sidoarjo and Gresik areas including SMAN 4 Surabaya, SMAN 15 Surabaya, SMAN 1 Krian, SMA Al Islam Krian and SMAN 1 Driyorejo. Each school involved one respondent class. This research conducted using a mix method research so that in this study, two types of approaches combined in research, namely a quantitative approach and a qualitative approach (Masrizal, 2011; Lestari et al., 2019).

The mix method approach in this study carried out by distributing questionnaires, there were eighteen questions, thirteen questions were multiple-choice questionnaires, and five items were essays on scientific literacy. There is a text on the mystery of the Banda 
Sea, which adapted from a book model of Scientific Literacy-Based Learning by Titin Sunarti, 2017 (Sunarti, 2017). Data collection carried out online by distributing questionnaires and questions via Google Form due to pandemic conditions that made it impossible to retrieve data offline. The questionnaire results transcribed and analyzed using four indicators of scientific literacy, namely explaining phenomena scientifically, evaluating and designing scientific investigations, interpreting data and providing scientific evidence and positive attitudes towards science. The answers of these students were categorized into four categories, namely not answering questions with a score of 0 , answering questions but not correctly answering questions with a score of 1 , answering questions correctly with a score of 2 and answering questions very accurately with a score 3 .

The research data from the results of the questionnaire were then analyzed using regression and correlation tests before using the regression test and correlation test using the prerequisite test, namely the normality test, homogeneity test and linearity test. Where a simple linear regression test is used to determine the effect of student interest on the results of scientific literacy, the correlation test was used to determine the relationship between students' interest in learning physics and the consequences of scientific literacy. In the correlation test using the hypothesis $\mathrm{H} 0$ and $\mathrm{H} 1$, where $\mathrm{H} 0$ there is no relationship between students 'interest in learning physics and the results of scientific literacy, and $\mathrm{H} 1$ there is a relationship between students' interest in learning physics and the consequences of scientific literacy. By looking at the significance value, if sig. $<0.05$ then there is a significant correlation so that $\mathrm{H} 1$ is accepted and if it is sig. $>0.05$, there is a significant correlation so that H0 is assumed (Creswell \& Clark, 2007; Suprapto et al., 2018).

\section{RESULTS AND DISCUSSION}

Based on the results of research that has carried out for a quantitative approach with regression tests and correlation tests through the SPSS application. Simple linear regression test used to measure the influence of students' interest in learning on the results of scientific literacy skills. The correlation test used to determine the relationship between students' interests in learning and the effects of scientific literacy skills shown in the Table 1 (Sugiyono, 2015; Creswell, 2010)

Table 1. The results of the regression test analysis.

\begin{tabular}{cccccc}
\hline Model & \multicolumn{2}{l}{ Unstandardzed Cofficients } & $\begin{array}{c}\text { Standardzed } \\
\text { Coefficients } \\
\text { Beta }\end{array}$ & $\mathrm{T}$ & Sig. \\
\hline (Constant) & 4.486 & .0769 & & 5.835 & .000 \\
Interest & .121 & .072 & .118 & 1.679 & .095 \\
\hline
\end{tabular}

In Table 1, it can be seen that the significance value is 0.095 . By using the basis of decision making by looking at the significance value. In table one, the significance value is greater than the 0.05 probability, which means that there is no effect on students 'interest in learning on the results of students' scientific literacy abilities. This is because in filling out the questionnaire interest in learning physics has a higher score than in filling out scientific literacy questions which have a lower score. The low score of scientific literacy questions was caused by many students who did not answer the questions, and responded to questions but still not quite right. Therefore, the scores of the students' scientific literacy questions were low. 
Table 2. The results of the correlation test analysis.

\begin{tabular}{|c|c|c|c|c|}
\hline \multirow{2}{*}{\multicolumn{2}{|c|}{ Interest }} & & Interest & Total Score \\
\hline & & Pearson Correlation & 1 & .118 \\
\hline & & Sig. (2-tailed) & & .095 \\
\hline & & $\mathrm{N}$ & & 201 \\
\hline Results & of & Pearson Correlation & .118 & 1 \\
\hline Scientific & literacy & Sig. (2-tailed) & .095 & \\
\hline skills & & $\mathrm{N}$ & 201 & 201 \\
\hline
\end{tabular}

Based on Table 2, it is known that the significance value is Sig. (2-tailed) between the students 'interest $(\mathrm{X})$ and the results of the students' scientific literacy skills $(\mathrm{Y})$ is 0.095> 0.05, which means that $\mathrm{H} 0$ is accepted and $\mathrm{H} 1$ is rejected. H0 took means that there is no significant correlation between students' interest in learning and the results of scientific literacy skills. Simple analysis (r) shows that the correlation between students' interests and the consequences of scientific literacy skills $(\mathrm{r})$ is 0.118 . This means that there is a shallow relationship between students 'interest in learning and the consequences of high school students' scientific literacy skills. In accordance with the research that has been done where the interest of students in learning has a higher score than the score of the results of literacy skills.

From the results of the high school student questionnaire, it can see that more students are interested in learning physics. A total of 166 students who were interested and 35 students who were not interested in learning physics.

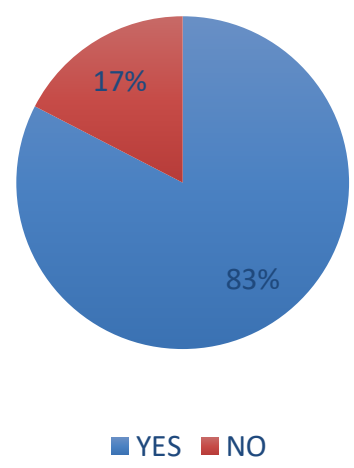

Figure 1 Graph of the percentage of students' interest learning physics.

It can see in Figure 1 that the students' interest in learning physics is very much, while those who are not interested in learning physics are only a few. From the results of interviews with several students, the reason they are interested in learning physics is that many physics concepts can be applied in everyday life. Physics is not only about formulas but many physics concepts that can use in everyday life. Therefore many students answered that physics is interesting to learn. Figure 2 is a graph of the results of students in answering the essay questions on the mystery of the Banda Sea. 


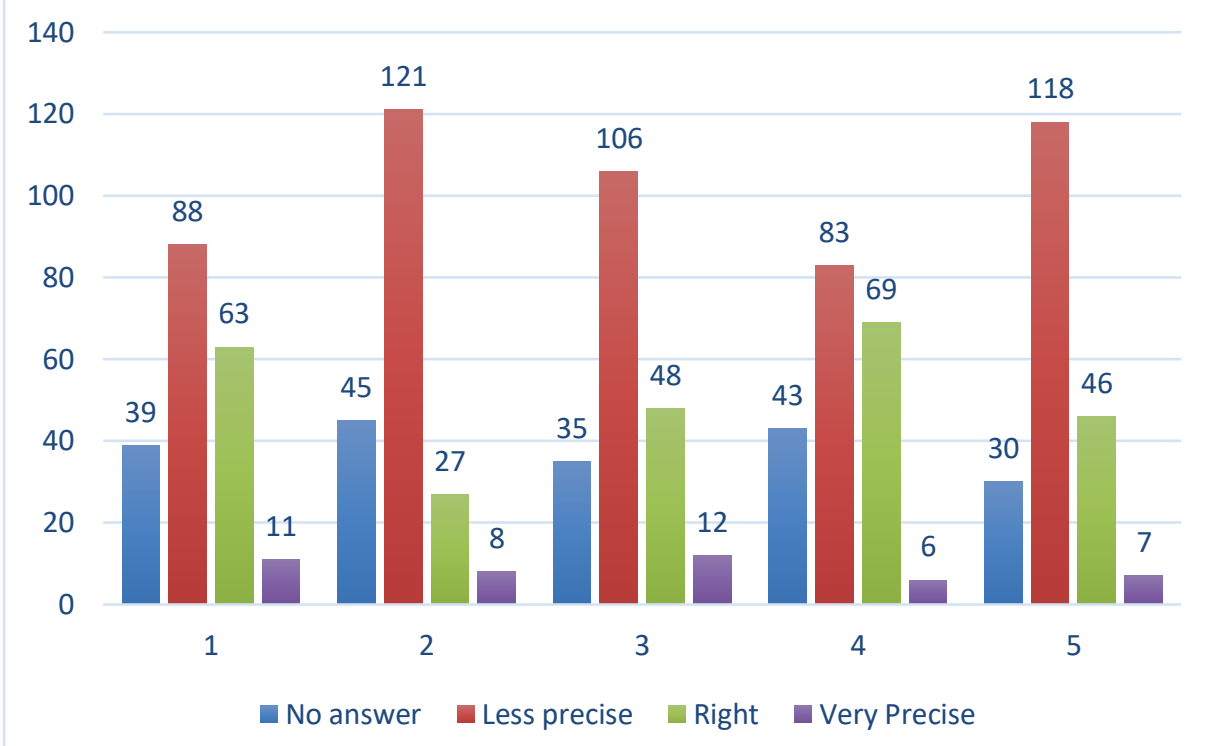

Figure 2 Graph of the results of scientific phenomena essay questions on the number of students who answered.

Based on Figure 2, it can seem that of all the questions regarding the mysterious Banda Sea phenomenon, and there are still many students who answer incorrectly. In question number 2 , there were a lot of students who answered incorrectly compared to the other five questions. In question number two, namely "Try to explain the concept of science and provide a brief explanation that you have mentioned in answer number 1?" In this case, it means that students do not understand the scientific concepts that exist in the mysterious phenomenon of the Banda Sea. So that students cannot explain briefly the scientific concepts contained in the mysterious phenomenon of the Banda Sea. The following are some of the answers from students regarding question number 2 and are classified as appropriate because students can explain the concept of science by applying existing scientific knowledge.

Because of the problem of the submarine using a static fluid with hydrostatic pressure, namely the stress caused by the force that exists on the liquid against a compressed area at a certain depth. (Nurus) The pressure is the amount of force acting on an object per unit area. The amount of pressure influenced by the force $(F)$ and the surface area of the base $(A)$. The amount of pressure is inversely proportional to the surface area of an object's command. The larger the surface area of the bottom of an item, the smaller the stress that will arise. (Aditya)

The deeper it goes into the sea, the greater the pressure generated, because the water pressure is directly proportional to density, earth's gravitational force, and depth. (Najwa)

In the fourth question, which is "Write down some unscientific questions (cannot be tested through a scientific investigation)" it can see that the number of students who answered is less precise than the other five questions. which satisfies the second scientific literacy indicator evaluating and designing scientific investigations. Students understand more about unscientific questions than scientific questions because, in the fourth question, students answer more correctly than on question three regarding scientific questions. The following are the answers of students in the right category.

Are there UFOs in the Banda Sea? (Najwa)

How would someone feel if they entered the ocean vortex? (Nadia)

Is it sure that the Banda Sea has something to do with magical things as said by eyewitnesses? (Shalom) 
The fifth question is "From the phenomenon of the Banda Sea Mystery, what conclusions can draw from the phenomenon above?" which fulfils the third indicator of scientific literacy, namely interpretation and providing scientific evidence by inferring the phenomenon of the Banda Sea. It can see that there are still many students who answer incorrectly as in question three. Which means that students do not understand the contents of the mystery of the Banda Sea so that they cannot conclude the phenomenon of the mystery of the Banda Sea. The following are some of the answers of students in the inappropriate category in answering question number five:

The Banda Sea is the deepest in the world (Danish)

That many mysterious events in the Banda Sea are difficult to prove scientifically (Fazle)

It can conclude that the sea in the world is very abundant and challenging to be in reach out even using various methods, in my opinion, is very difficult. (Maulana)

The fourth indicator is about Indicator 4 Positive Attitudes towards science. In this fourth indicator, data obtained through a questionnaire, which can be seen in Figure 3.

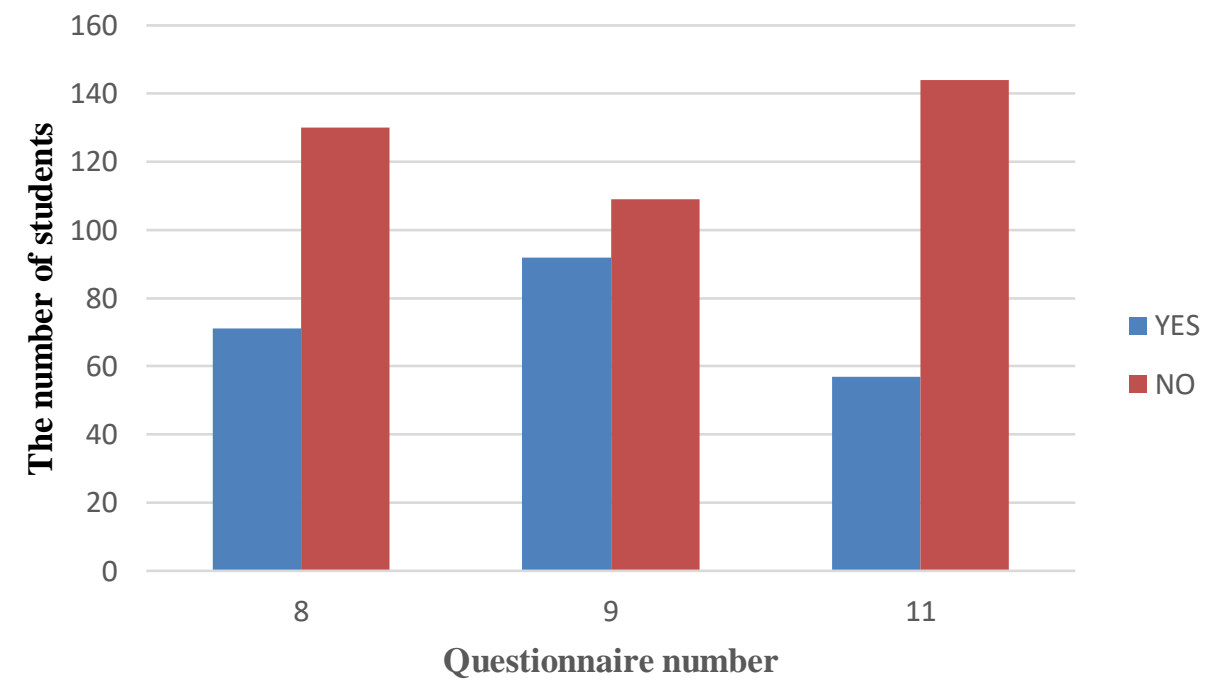

Figure 3 Questionnaire graph on the number of students who answered.

From Figure 3, the student questionnaire, which contains the questions from indicator four, namely regarding the attitude of students towards science is still low. It can see from the graph of Figure 3, where no answers from students dominate the three questionnaires. In the number eight questionnaire, which contains the interest of students regarding reading scientific phenomena, is still low. Then in the questionnaire number nine, which has about "Can you explain scientific phenomena by applying scientific knowledge?" Most of the students answered that they did not like reading scientific phenomena. Questionnaire number eleven, which contains "Have you ever carried out a scientific investigation based on scientific data in learning physics" and the answers of many students answered that they never did (Arifin \& Sunarti, 2017; Deta, 2017).

The results and discussion above, it can see from the effects of simple linear regression analysis that there is no influence on the interest of students. In contrast, the results of the correlation test, it can conclude that the part of students in learning physics is negatively related to the effects of students' scientific literacy skills. Then on the results of students 'scientific literacy abilities, of course, it can see that students' understanding of scientific literacy is still low. The first indicator to the fourth indicator the answers given by students, from questions regarding scientific phenomena to the questionnaire given, do not meet the hands of scientific literacy. So it can conclude that the understanding of scientific literacy is still low. It can see that there is still many students' interest in learning 
physics, but in the results of research, the ability of scientific literacy is still low. This is due to the lack of students in reading scientific phenomena. It is known from the results of interviews with several students who complained about a large amount of discourse on the questions given, as well as the difficulty of the questions they were working on. Students say that the problems that are often provided by the teacher are more questions that have no discourse. From the interviews of several students, which caused the low mastery of scientific literacy, including the lack of getting used to the learning process that supports students in developing scientific literacy. In line with Gustia Angraini's research, 2014, where there are factors that cause the low scientific literacy of students (Arifin \& Sunarti, 2017; Angraini, 2014; Hidayatulloh et al., 2015).

To improve students 'understanding of scientific literacy, it can be done by familiarizing students with each learning will begin to be able to read scientific literacy so that they are accustomed to scientific literacy so that it can increase students' interest and understanding in scientific literacy. Science literacy is very important for students because students will use the scientific process in problem-solving, decision making, and further understanding of society and the environment. To help solve problems entirely and precisely. Besides, with the scientific method, they can use higher thinking skills, not just talking. Some problems cannot solve only with opinions, but with scientific evidence to strengthen those opinions. For that, students need to learn related scientific literacy which has advantages in it (Susanti \& Jatmiko, 2016; Nurlailiyah \& Deta, 2015; Suliyanah et al., 2020).

\section{CONSLUSSION}

From the research that has done, it can conclude that students' understanding of scientific literacy is still low. The interest of students in learning physics does not affect the results of scientific literacy skills. Therefore, it can recommend that students can improve their understanding of scientific literacy by getting used to reading scientific literacy before learning begins so that students' interest and understanding of scientific literacy increases.

\section{RECOMMENTATION}

In the research that will carry out next, it suggested that researchers can examine directly with students. So that researchers can find out the abilities of students directly.

\section{ACKNOWLEDGMENTS}

This article is part of research on the scientific literacy of high school students. Therefore, the authors would like to thank all the students of SMAN 4 Surabaya, SMAN 15 Surabaya, SMAN 1 Krian, SMA Al Islam Krian and SMAN 1 Driyorejo. They have been willing to fill out the questionnaire and take part in further interviews.

\section{REFERENCES}

Abdullah, S. R. (2014). Pembelajaran Saintifik untuk Implementasi Kurikulum 2013. Jakarta: Bumi Aksara.

Amalia, A. (2015). Pengembangan Bahan Ajar IPA Berbasis Literasi Sains Bertema Sistem Navigasi. Skripsi. Universitas Negeri Semarang.

Angraini, G. (2014). Analisis Kemampuan Literasi Sains Siswa Sma Kelas X Di Kota Solok (161-170). Prosiding Mathematics and Sciences Education Reform. Jurnal of Research in Science Teaching (pp. 161-170). Department of Biology, Universitas Pendidikan Indonesia. 
Ardiansyah, A. A. I., Irwandi, D., \& Murniati, D. (2016). Analisis Literasi Sains Siswa Kelas XI IPA Pada Materi Hukum Dasar Kimia Di Jakarta Selatan. Jurnal Kimia dan Pendidikan, 1 (2), 149-161.

Ardianto, D., \& Rubini, B. (2016). Comparison Of Students' Scientific Literacy In Integrated Science Learning Through Model Of Guided Discovery And Problem Based Learning, Jurnal Pendidikan IPA Indonesia, 5 (1), 31-37.

Arifin, L., \& Sunarti, T. (2017). The Improvement Of Student's Scientific Literacy Through Guided Inquiry Learning Model and Flui Dynamics Topic. Jurnal Penelitian Fisika dan Aplikasinya (JPFA), 7 (2), 68-78.

Asyhari, A., \& Hartati, R. (2015). Profil Peningkatan Kemampuan Literasi Sains Siswa Melalui Pembelajaran Saintifik. Jurnal Ilmiah Pendidikan Fisika Al-BiRuNi, 4 (2), 179191.

Azizah, R., Yuliati, L., \& Latifah, E. 2015. Kesulitan Pemecahan Masalah Fisika Pada Siswa Sma. Jurnal Penelitian Fisika dan Aplikasinya, 5 (2), 44-50.

Creswell, J. W. (2010). Research Design : Pendekatan Kualitatif, Kuantitatif, dan Mixed. Yogyakarta: Pustaka Pelajar.

Creswell, J. W., \& Clark, V. P. (2007). Designing and conducting mixed methods research. 2nd ed. Thousand Oaks: Sage Publications.

Demirel, M., \& Belk1z, C. (2015). Prospective Science and Primary School Teachers' Selfefficacy Beliefs in Scientific Literacy. Procedia - Social and Behavioral Sciences. 191, 1903 $-1908$.

Deta, A. U. 2017. Peningkatan Pemahaman Materi Kuantisasi Besaran Fisis Pada Calon Guru Fisika Menggunakan Metode Diskusi Kelas Dan Scaffolding. Jurnal Ilmiah Fisika Al BiRuNi, 06 (2), 201-207.

Gurses, A., Gunes, K., Barin, B., \& Eroglu Z. (2015). Relation Between Pre-Service Chemistry Teachers' Science Literacy Levels And Their Some Scientific Process Skills. Procedia - Social and Behavioral Sciences, 197, 2395 - 2402.

Hidayatulloh, M., Humairoh, F., Wachidah, U., Iswati, D. A., \& Suliyanah. (2015). Pengembangan Perangkat Pembelajaran Untuk Mereduksi Miskonsepsi Siswa Pada Materi Rangkaian Listrik dengan Scientific Approach. Jurnal Penelitian Fisika dan Aplikasinya (JPFA), 5 (1), 28-32.

Karim, S., Prima, E. C., Saepuzaman, D., \& Nugaha, M. G. (2017). Recostructing the physics teaching didactic based on marzano's learning dimension on training the scientific literacies. Journal of Physics: Conference Series, 812(1): 012102.

Khaeroningtyas, N., Permanasari, A., \& Hamidah. (2016). Stem Learning In Material Of Temperature And Its Change To Improve Scientific Literacy Of Junior High School Students. Jurnal Pendidikan IPA Indonesia, 5 (1), 94-100.

Lestari, N. A., Jatmiko, B., Dwikoranto., Prahani, B. K., Deta, U. A., \& Bachtiar, R. W. (2019). Pre-service Physics Teachers Perception about Concept Map, Mind map, and Link Map for Innovative Learning. Journal of Physics: Conference Series. 1417, 012092.

Litbang Kemdikbud. (2013). Kurikulum 2013: Pergeseran Pradigma Belajar Abad-21. Retrieved November 20, 2020, from http://litbang.kemdikbud.go.id/index.php/index-berita-kurikulum/243- kurikulum2013-pergeseran-paradigma-belajar-abad-21.

Masrizal. (2011). Mixed Method Research. Jurnal Kesehatan Masyarakat, 6(1), 53-56.

Nurlailiyah, A., \& Deta, U. A. (2015). Studi Korelasi Antara Kemampuan Matematika dengan Hasil Belajar Fisika di SMA PGRI Sumberrejo Bojonegoro Tahun 2014/2015. Jurnal Penelitian Fisika dan Aplikasinya (JPFA), 5 (2), 64-69.

OECD. (2015). Programme for international student assessment (PISA). New York: Columbia University. 
Rahayu, S. (2014). Menuju Masyarakat Berliterasi Sains : Harapan dan Tantangan Kurikulum 2013. Seminar Nasional Kimia dan Pembelajarannya (pp. 27-40). Malang, Indonesia : Department of Chemistry, Universitas Negeri Malang.

Rohman, S., Ani, R., \& Sulhadi. (2017). Analisis Pembelajaran Fisika Kelas X SMA Negeri di Kota Cirebon Berdasarkan Literasi Sains. Physics Communication, 1 (2), 12 18.

Septiani D., Widiyawati, Y., \& Nurwahidah, I. (2019). Pengembangan Instrumen Tes Literasi Sains Pisa Aspek Menjelaskan Fenomena Ilmiah Kelas VII. Science Education and Application Journal (SEAJ), 1 (2), 46-55.

Sugiyono. (2015). Metode penelitian kombinasi (mix methods). Bandung : Alfabeta.

Sukowati, D., Rusilowati, A., \& Sugianto. (2017). Analisis Pembelajaran Fisika Kelas X SMA Negeri di Kota Cirebon Berdasarkan Literasi Sains. Physics Communication, 1 (2), 12-18.

Suliyanah, Oktavina, R., \& Deta, A.U. 2020. The Feasibility of Student Worksheet based on Collaborative Creativity to Improve Students Creative Thinking Skill. Berkala Ilmiah Pendidikan Fisika, 8 (2), 91-102.

Sunarti, T. (2017). Buku Model Scientific Literacy Based Learning. Jaudar Press : Surabaya.

Suprapto, N., Lin, H.-H, Ku, C.-H., \& Chang, T.-S. (2018). "Unless you can explain" Voices from graduate students and their Professor regarding the importance of science communication courses. Paper submitted to The Qualitative Report.

Susanti, W., \& Jatmiko, B. (2016). Implementasi Model Pembelajaran Kooperatif Tipe TAI (Team Assisted Individualization) Untuk Meningkatkan Hasil Belajar Fisika SMA Pada Materi Elastisitas. Jurnal Penelitian Fisika dan Aplikasinya (JPFA), 6 (1), 2633.

Wen, C.-T., Liu, C.-C., Chang, H.-Y., Chang, C.-J., Chang, M.-H., Chiang, S.-H. F., Yang, C.-W., \& Hwang, F.-K. (2020). Students' guided inquiry with simulation and its relation to school science achievement and scientific literacy. Computers \& Education. 149 (103830), 1-14.

Wulandari N., \& Sholihin, H. (2016). Analisis Kemampuan Literasi Sains Pada Aspek Pengetahuan Dan Kompetensi Sains Siswa Smp Pada Materi Kalor. EDUSAINS, 8 (1), 66-73. 